\title{
Salário Mínimo, Crescimento e Ajuste Fiscal e Financeiro
}

\author{
Demian Castro* \\ Igor Zanoni C. Carneiro Leão ${ }^{* *}$
}

Em 2004, segundo critérios do Banco Mundial elaborados a partir da paridade do poder de compra, o Brasil permaneceu como a nona economia do mundo, com um produto interno bruto de 1,48 trilhão de Dólares, embora tenha ficado na $86^{\text {a }}$ posição em termos per capita, com um PNB (Produto Nacional Bruto) de oito mil e vinte Dólares. Outros países ditos emergentes ganharam posições mais rapidamente que o Brasil, refletindo-se no resultado do PNB per capita, como é o caso da Argentina e também do Chile. Note-se que a China é hoje a segunda economia mundial, quase o dobro da japonesa que, por sua vez, mantém-se pouco acima da indiana em termos totais. Estes dados mudam lentamente num contexto de crescimento moderado da economia mundial e da brasileira, mas é marcante a ascensão de certas economias como a Índia e mesmo a Argentina.

Como afirma Marcio Pochmann (2005), o Brasil, após um longo período de crescimento no pós-guerra, atravessou entre 1980 e 2004 uma longa fase de estagnação da renda per capita, que cresceu em média apenas 0,4\%, enquanto entre 1950 e 1980 crescera à média de 5,6 \% ao ano. No último período viveu-se um típico movimento de stop and go em que prevaleceu uma média de crescimento total e per capita muito baixa, apresentando desde o início do Plano Real uma expansão mais acelerada entre 1994-96 e em 2000.

A partir de 1994, a enorme desigualdade dos rendimentos do trabalho no Brasil, mesmo com menor inflação e queda de preços relativos de produtos de exportação e importação, persistiu apesar de uma retomada da atividade da economia até 1996. Os empregos mais bem remunerados das grandes empresas perderam-se no novo formato empresarial que marca essa década e o baixo nível salarial aumentou nas ocupações de entrada no mercado de trabalho, tipicamente para jovens, mas que passaram a ser divididas com adultos mais velhos. Ao mesmo tempo os baixos salários não estiveram nesse período relacionados com o salário mínimo legal, que perdeu poder de compra entre 1990-94 e recuperou-se lentamente a partir dessa data.

\footnotetext{
* Doutor em Economia pela Unicamp e Professor da UFPR. Endereço eletrônico: demian@ufpr.br.

** Doutor em economia pela Unicamp e Professor da UFPR. Endereço eletrônico; igorza@bol.com.br.
} 
O nível de baixos salários se recupera até 97 mas perde força a partir daí, prejudicados pela desvalorização do real e pela baixa elasticidade do emprego em relação ao produto. Tudo isso num contexto de um PIB muito contido pela política macro-econômica e pelos juros altos entre 2000 e 2004, aponta Baltar (2005), geraram empregos assalariados formais em maior volume, mas com baixa remuneração dado o contexto já mencionado da política macro-econômica: "prevaleceu a redução do salário médio e, neste contexto, a continuação da recuperação do valor do salário mínimo contribuiu para evitar a queda dos salários mais baixos, colaborando também para a continuação da diminuição da desigualdade dos rendimentos do trabalho, fazendo com que a diminuição das diferenças de rendimento fosse maior do que a queda do rendimento médio".

Tudo somado, hoje há uma desigualdade de rendimentos do trabalho semelhante ao do início dos anos 70 com o valor do salário mínimo bem menor, apontando para o fato de uma piora na distribuição de renda e para a frustração das expectativas de que a democracia, junto com o avanço no aparelho produtor de bens, tornaria possível a existência de relações de trabalho "mais civilizadas" e melhor distribuição de renda. Ao contrário, observou-se uma crise na acumulação de capital produtivo desde o início dos anos 80, com o país avançando rumo ao ciclo de financeirização da riqueza, observando-se uma transferência crescente do fluxo de renda gerado pela produção e trabalho para os ganhos financeiros apropriados por uma parcela muito pequena da sociedade.

Entre maio de 2004 e maio de 2005, o quadro acima se traduziu numa estagnação da remuneração média das pessoas ocupadas e dos empregados no setor privado, e num leve crescimento dos empregados no setor público. O rendimento médio das pessoas ocupadas em maio de 2005 alcançou 932,80 Reais em seis regiões metropolitanas. Por outro lado, segundo dados da pesquisa mensal de empregos do IBGE, a taxa de desemprego se manteve em níveis altos e estáveis desde 1998, ao mesmo tempo em que cerca da metade das pessoas ocupadas receberam até dois salários mínimos mensais. Nos meses de maio e junho de 2005, observou-se a desaceleração do saldo do emprego formal, após crescimento anual até maio, puxado especialmente pela expansão na agroindústria, a qual hoje se encontra ameaçada pela valorização do real e por efeitos climáticos.

A desestruturação do mercado de trabalho brasileiro foi reconhecida implicitamente pelo governo Lula ao instituir recentemente o Conselho Nacional do Salário Mínimo, visando formular uma política nacional de médio prazo de valorização do mesmo. Essa medida beneficiaria mais de um terço dos trabalhadores ocupados, ou 22 milhões de trabalhadores, 
que ganham até um salário mínimo e atingiria cerca de 22 milhões de beneficiários diretos e 55 milhões de beneficiários indiretos dos programas que fazem parte da seguridade social.

Segundo Dedecca (2005), a estratégia de valorização do salário mínimo aparentemente considerada pelo governo no último reajuste parte de alguns pressupostos básicos. O primeiro é que o longo período de desvalorização do rendimento exige uma política de revalorização de médio prazo. Esta deve levar em conta as condições de crescimento do produto e o aumento da produtividade da economia brasileira de forma a não causar constrangimentos para a dinâmica da atividade produtiva que sirva mesmo como uma de suas alavancas. Finalmente, que essa valorização deve se compatibilizar com as flutuações do PIB e da produtividade média da economia, vinculando-se, ao menos, à variação do salário mínimo e ao crescimento do produto da produtividade.

Por outro lado, hoje no Brasil não se trata da necessidade da elevação do valor nominal do salário mínimo, mas da compatibilização de distintas áreas da política pública, que dê dinamismo à estrutura produtiva, ao padrão de consumo da população e a uma política de pleno emprego, capazes de em conjunto fazer avançar a distribuição de renda e diminuir as pressões sociais hoje existentes no Brasil. Nesse sentido, o estabelecimento de diretrizes para o desenvolvimento social e econômico alcança áreas como o abastecimento popular, as diretrizes para a política industrial e agrícola, bem como a política urbana, que já em si atinge questões diversas como a infra-estrutura urbana, moradia popular, custo do transporte coletivo, preço de tarifas públicas e necessidade de subsídios aos preços públicos.

Estas diretrizes supõem um padrão de condução das contas públicas que reverta a regressiva carga tributária, estimule o gasto social, vincule receitas fiscais sociais e universalize o acesso à bens de serviços públicos. Nesse sentido, o padrão de ajuste fiscal predominante nas duas últimas décadas deve ser abandonado em prol de uma menor ortodoxia na contenção do gasto público.

É necessário, em suma, um esforço capaz de garantir um crescimento continuado do produto e a materialização de condições mínimas para estruturar o mundo do trabalho, em cuja direção caminha a valorização necessária do salário mínimo. Este caminho, entretanto, supõe enfrentar a aguda questão representada pelo passivo externo e interno dos vários níveis de governo, que comprometem o crescimento e a segurança social, e corrói os vínculos sociais e políticos mais fundamentais numa sociedade com os problemas históricos do Brasil. 


\section{Bibliografia}

Pochmann,M.(2005). Déficit público nominal zero e custos sociais, UNICAMP.

Baltar, P.E. (2005). Desigualdade e rendimentos do trabalho e salário minimo na década de 90, in: CESIT, UNICAMP, Carta Social e do Trabalho.

Dedecca, C.S. (2005).Uma política de valorização do salário minimo, in: CESIT, UNICAMP, Carta Social e do Trabalho.

Pesquisa mensal de emprego, IBGE.

Folha de São Paulo, Caderno Dinheiro. 